\title{
STUDY ON POST EVALUATION OF HIGH-SPEED RAILWAY BASED ON FAHP AND MATLAB SIMULATION CALCULATION
}

\author{
Yongzhi Chang, Suocheng Dong
}

Original scientific paper

Targeted at constructing a scientific post-evaluation system, this paper establishes 4 first indices, 9 secondary indices, and 32 third indices on the basis of post evaluation analysis of high-speed railway construction projects. With Harbin-Dalian High-speed Railway as the object of empirical analysis, the author builds a model through the fuzzy analytic hierarchy process (FAHP), and carries out simulation calculation with Matlab. Finally, the author draws the conclusions that Harbin-Dalian High-Speed Railway gets good results. Specifically, the routes selected by survey and design are appropriate, work safety is ensured during the construction, the project operation has stimulated the GDP, the per capita GNP of residents along the high-speed railway has increased, and people's satisfaction and willingness to participate in high-speed railway projects have been improved. Nevertheless, acoustic and radiation protection measures should be adopted to improve transport efficiency, increase project revenue, and reduce the environmental pollution caused by highspeed railway operation.

Keywords: fuzzy analytic hierarchy process; high-speed railway construction project; Matlab; post evaluation

Studija o naknadnom vrednovanju željeznice visoke brzine na temelju izračuna simulacije FAHP i MATLAB

Izvorni znanstveni članak

Usmjeren na izgradnju znanstvenog sustava naknadne procjene, ovaj rad definira 4 prva indikatora, 9 drugih indikatora i 32 treća indikatora na temelju analize naknadne procjene projekata željezničkih pruga visokih brzina. S Harbin-Dalian željeznicom visoke brzine kao objektom empirijske analize, autor gradi model kroz neizraziti analitički hijerarhijski proces (FAHP) te provodi simulacijski izračun s Matlabom. Konačno, autor zaključuje da HarbinDalian željeznica velike brzine postiže dobre rezultate. Naime, prikladni su putovi odabrani anketom i projektom, tijekom izgradnje osigurana je sigurnost na radu, projekt je stimulirao BDP, porastao je BDP po glavi stanovnika duž željezničke pruge te zadovoljstvo i spremnost na sudjelovanje ljudi u željezničkim projektima viskokih brzina. Ipak, trebaju se usvojiti mjere zaštite od buke i zračenja radi poboljšanja učinkovitosti prijevoza, povećanja prihoda od projekta i smanjenja onečišćenja okoliša uzrokovanog željezničkim prometom visoke brzine.

Ključne riječi: fuzzy analitički hijerarhijski proces; Matlab; post evaluacija; projekt izgradnje željeznice visoke brzine

\section{Introduction}

High-speed railway is one of the most important breakthroughs in passenger transport technology made in the $20^{\text {th }}$ century, it holds much more significance than high speed. High-speed railway brings about a safe, comfortable and efficient mode of transport, injects new vitality into existing railway transport system and becomes a synonym for modern society [1-3]. Opened on October $1^{\text {st }}, 1964$, the Shinkansen in Tokyo and Osaka marks the dawn of the era of high-speed railway [4]. In the first 40 years of operation, Japan Shinkansen carries an average number of 100 million passengers each year. At the sight of Japan's success, European nations quickly followed suit. High-speed railways sprung up across Europe, such as Train à Grande Vitesse (TGV) in France (1981), Direttissima in Italy (1988), Intercity Trains (ICE) in Germany (1991), and Alta Velocidad Española (AVE) in Spain (1992), not to mention the famous Eurostar which links up Britain and France across the English Channel (1994) [5]. Elsewhere in the world, the US unveiled the first high-speed railway in North America, the Acela Express, in 2000. Korea Train Express (KTX), the Korean version of high-speed railway, also went live in 2004. Suffice it to say that almost every developed country now has high-speed railway in operation [5]. By 2009 , the total length of high-speed railways that were completed had reached $10,739 \mathrm{~km}$, and there were another $13,469 \mathrm{~km}$ under construction [6]. The International Union of Railways suggests that there is still a lot of room for high-speed railway to expand and the world's highspeed railway mileage is going to reach $250,000 \mathrm{~km} \mathrm{[7].}$

Since the beginning of $21^{\text {th }}$ Century, China has been raising the speed of existing railways and using ballastless tracks on a small scale. In this way, China accumulated valuable experience and technical expertise for highspeed construction. In 2008, Beijing-Tianjin Intercity Railway was opened up. The line accommodates trains travelling at a maximum speed above $300 \mathrm{~km}$, faster than that of any other Chinese railways at that time. A boom of high-speed railway construction ensued. By the end of 2015, China has built the world's longest high-speed network, consisting of 71 high-speed lines (segments) and $23,600 \mathrm{~km}$ of route in service. Many other high-speed railway projects are under construction. In light of the universally recognized high-speed railway development in recent years and with the "going global" process of China's high-speed railway in full swing, the author believes China should make full use of its advantages in high-speed railway by building a transport network linking up the places along the Silk Road economic zone. The effort will help with the early realization of the strategic conception on the Silk Road economic zone, and give a huge momentum to "the Belt and Road Initiative" strategic vision of China [8].

Because a high-speed railway project requires large investment, involves a wide range of affairs, and affects people's livelihood, it is necessary to carry out a systematic and objective post evaluation on the purpose, implementation, economic benefit, function, and influence of the project after it has passed completion acceptance and come into service. In November 2008, the NDRC issued the Circular Concerning Administrative Measures for Post Evaluation of Central Governmentfunded Projects (for trial implementation) (NDRC/Investment [2008] No. 2959) [9]. Applicable to all central government-funded projects with Feasibility Study Report approved by the NDRC, these measures 
require that after the project has been completed and put into service/operation for a certain period of time, a comparative study shall be conducted between the actual effects of the project and the main contents in the Feasibility Study Report and the Approval Documents so as to identify gaps and causes to the gaps, summarize lessons learned, put forward countermeasures, and continuously improve investment decision-making and investment efficiency.

The direct economic benefit is not the main consideration when Europe and America and other countries spend a great deal of effort developing highspeed railway projects. Therefore, the post-evaluation of high-speed railway construction project research does not see system report. The only report is focused on the cost and benefit, evaluation of regional economic and environmental effects. Levinson et al. [10] divide highspeed railway project cost into four categories: infrastructure cost, operating cost, passenger cost and social cost. Qu [11] splits the cost into three types: infrastructure cost, operating cost, and external cost, and adopts different cost estimation methods for each type. When it comes to construction cost, Campos et al. [2], citing the study by the International Union of Railways (UIC) in 2005, hold that the cost of a high-speed railway project should be broken down into such three categories as the planning and land cost, infrastructure construction cost and the supporting facilities construction cost, and suggest that labor cost represent the largest share of operating cost in each category. Besides, Campos et al. [2] quote data from Consulting Group for Policy Analysis and Implementation, Züri and Institute for Economic Policy Research (INFRAS/IWW) 2000, pointing out that external cost is incurred by accidents, noise, air pollution, climate change, urban effect, and upstream or downstream effects. In spite of varied analysis methods, the scholars draw similar conclusions that high-speed railway project has a high cost and fixed cost takes up a large share in construction cost [12]. Plus, as passenger demand is critical to revenue estimation, a high-speed railway must link up the metropolitan areas that are densely populated, heavily congested, and lacking air routes [5], and requires seamless transfer to other modes of transport. To evaluate the regional economic effect of an existing high-speed railway project, scholars construct their models mainly with New Economic Geography and Input-Output Analysis. During model analysis, some scholars study the effect of accessibility on regional economic development with the Difference-In-Difference (DID) method [13]. To analyze the accessibility changes brought by high-speed railway project, Lairdet al. [14] combine the transportation system model and multiregional input-output model into a multiregional integrated transportation input-output model and use it to analyze the accessibility changes brought by high-speed railway project, and to ascertain the high-speed railway project's effect on regional economic development. In these studies, the accessibility is mostly calculated with the geographic information system (GIS) toolbox for network accessibility analysis. Moreover, some scholars build a supply-oriented regional economic growth model [15]. To estimate the high-speed railway project's influence on labor demand, Guirao et al. [16] rely on a commuter location selection model, a spatial general equilibrium model for commuting, and the input-output matrix to estimates the household migration and employment flow resulting from residence relocation and reduction in transport cost. In respect to the mechanism of high-speed railway project, location selection models enjoy high popularity among scholars. A typical one is the discrete selection model of office location based on random utility maximization (RUM) developed by BazinBenoit et al. [17]. The nested-logit model (NLM) is used to establish the model. Vendor data is obtained mainly by means of questionnaires, telephone interviews and e-mail interviews [17]. In addition, in the study of the effect of high-speed railway project on house prices, scholars mostly resort to utility analysis [18].

At present, little research has been conducted on the post evaluation of high-speed railway project in China. Zhang [19] has laid a solid foundation for later research on post evaluation of railway projects. After discussing the operation mechanism of post evaluation for railway construction projects, he puts forward systematic theory on post evaluation for railway construction projects, which consists of such 7 aspects as post evaluation of construction process, post evaluation of financing plan, post evaluation of national economy, post evaluation of environmental effect, post evaluation of social effect, and post evaluation of sustainable development. Besides, he proposes the random evaluation method for post evaluation of finance, and function coefficient method for the post evaluation of sustainable development. Zhang [20] carries out a two-stage analysis of the performance of China's railway through data envelopment analysis (DEA). In addition, a few scholars in China have studied the index system, content and method of the post evaluation on railway construction projects.

The post evaluation of high-speed construction project should be performed with feasible methods. The existing methods include fuzzy mathematics [21,22], neural network [23], analytical hierarchy process (AHP) [24], fault tree analysis [25], multi-criteria decisionmaking [26, 27], etc. Nevertheless, the post evaluation of high-speed railway construction project has a great uncertainty and covertness because it is a decisionmaking process involving multiple uncertain indices. Besides numerous quantitative indices, the evaluator has to take into account a large number of qualitative indices. The fuzzy mathematics theory is presented as a good solution to the issue as it is capable to integrate the uncertain information and perform comprehensive analysis. However, if fuzzy mathematics theory is used alone, it has some shortcomings in determining the weight of a complex index system. In contrast, the AHP takes the object as a whole and makes decision through decomposition, comparative judgment and comprehensive thinking. The AHP makes the systems much more organized as it divides the factors of a complex system into interconnected, orderly hierarchies. Then, it makes judgment according to object reality, quantifies the importance of each hierarchy relative to the other hierarchy, and determines the weight of each hierarchy mathematically. In view of the above-mentioned facts, and in light of the characteristics of high-speed construction projects, the author constructs a complete index system for post evaluation of high-speed railway construction projects. It contains the four aspects of process evaluation, economic benefit evaluation, impact evaluation and sustainability evaluation, and adopts FAHP to establish the post evaluation model for highspeed construction project. In addition, the author 
simulates the evaluation results with the aid of the powerful drawing and computing capability of Matlab. To make the program more targeted to the issue, it is prepared with object-oriented way of thinking and steps rather than procedural thinking. This paper simplifies the modeling process for engineering designers, providing an effective tool for post evaluation of high-speed railway project.

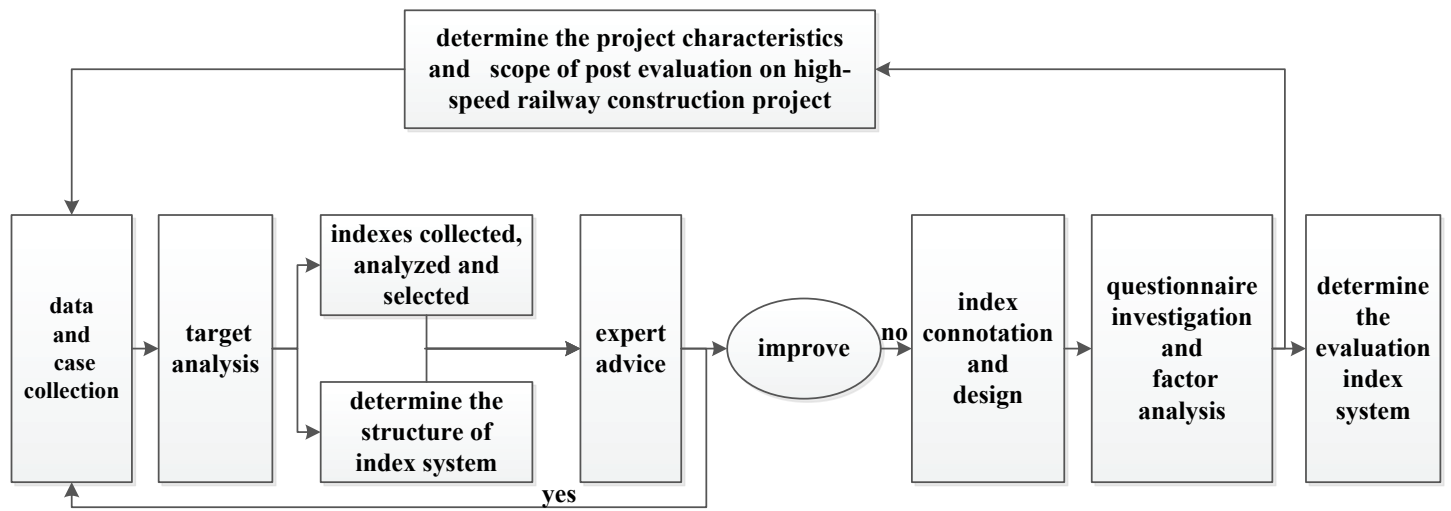

Figure 1 The establishing process of index system of post evaluation on high-speed railway construction project

\begin{tabular}{|c|c|c|c|}
\hline Total index & First index & Secondary index & Third index \\
\hline \multirow{32}{*}{$\begin{array}{l}\text { Index system of post } \\
\text { evaluation on high- } \\
\text { speed railway } \\
\text { construction project } \\
X\end{array}$} & \multirow{10}{*}{ Process evaluation $F_{1}$} & \multirow{3}{*}{$\begin{array}{l}\text { Process evaluation of pre-bid } \\
\text { decision-making } S_{1}\end{array}$} & Necessity of project construction $T_{1}$ \\
\hline & & & Scientific decision-making program $T_{2}$ \\
\hline & & & Survey and design $T_{3}$ \\
\hline & & \multirow{5}{*}{ Construction process evaluation $S_{2}$} & Safety management $T_{4}$ \\
\hline & & & Main technical indices $T_{5}$ \\
\hline & & & Construction quality $T_{6}$ \\
\hline & & & Investment control $T_{7}$ \\
\hline & & & Time limit $T_{8}$ \\
\hline & & \multirow{2}{*}{ Operation process evaluation $S_{3}$} & Preparation of operational effect $T_{9}$ \\
\hline & & & Operation management level $T_{10}$ \\
\hline & \multirow{6}{*}{$\begin{array}{l}\text { Evaluation of economic } \\
\text { benefits } F_{2}\end{array}$} & \multirow{2}{*}{ Financial benefit evaluation $S_{4}$} & Payback period of investment $T_{11}$ \\
\hline & & & Debt service coverage ratio (DSCR) $T_{12}$ \\
\hline & & \multirow{4}{*}{$\begin{array}{l}\text { National economic benefits } \\
\text { evaluation } S_{5}\end{array}$} & Contribution to GDP $T_{13}$ \\
\hline & & & Freight cost reduction benefits $T_{14}$ \\
\hline & & & Economic internal rate of return (EIRR) $T_{15}$ \\
\hline & & & Economic net present value (ENPV) $T_{16}$ \\
\hline & \multirow{10}{*}{ Effect evaluation $F_{3}$} & \multirow{8}{*}{ Social effect evaluation $S_{6}$} & Drive labor and employment $T_{17}$ \\
\hline & & & Appreciation rate of land and house $T_{18}$ \\
\hline & & & $\begin{array}{l}\text { Outage rate of cars and planes along the line } \\
T_{19}\end{array}$ \\
\hline & & & Increased transport capacity $T_{20}$ \\
\hline & & & Average travel time $T_{21}$ \\
\hline & & & Per Capita GNP along the line $T_{22}$ \\
\hline & & & $\begin{array}{l}\text { Compensate degree of benefit damage group } \\
T_{23}\end{array}$ \\
\hline & & & Effect on national image $T_{24}$ \\
\hline & & \multirow{2}{*}{ Environmental effect evaluation $S_{7}$} & Ecological environmental effect $T_{25}$ \\
\hline & & & Project pollution control $T_{26}$ \\
\hline & \multirow{6}{*}{$\begin{array}{l}\text { Sustainability evaluation } \\
F_{4}\end{array}$} & \multirow{3}{*}{$\begin{array}{l}\text { Evaluation of internal sustainability } \\
\text { factors } S_{8}\end{array}$} & Project management mechanism $T_{27}$ \\
\hline & & & Growth rate of traffic volume $T_{28}$ \\
\hline & & & Technical factors $T_{29}$ \\
\hline & & \multirow{3}{*}{$\begin{array}{l}\text { Evaluation of external sustainability } \\
\text { factors } S_{9}\end{array}$} & Benign circulation factors $T_{30}$ \\
\hline & & & Project satisfaction $T_{31}$ \\
\hline & & & Capital factors $T_{32}$ \\
\hline
\end{tabular}

\section{Construction of evaluation index system}

The author sets an interview outline based on literature review [19, 20] and field research, conducts systematic interviews on experts working in government units, construction contractors, design companies, railway transportation departments, consultation firms, and scientific research institutes, and prepares a questionnaire for post evaluation of high-speed construction project on the basis of interview findings. After pretest among selected samples and reliability and validity tests, the questionnaire is optimized, improved and finalized. Next, the author extracts common factors with factor analysis method and field survey. Giving comprehensive consideration to the interrelation between the various factors, the author finally constructs a post evaluation index system for high-speed construction projects. Four layers of indices are introduced, namely the target layer 
(main index), criteria layer (first indices), sub-criteria layer (secondary indices), and solution layer (third indices). See Fig. 1 for the construction process of the post evaluation index system for high-speed construction projects, and see Tab. 1 for the post evaluation index system.

\section{The principles of FAHP}

In 1965, Zadeh [28] a famous cybernetics scholar at the University of California, put forward the concept of fuzzy sets. The concept lays the foundation of fuzzy set theory and its applications, marking the birth of fuzzy mathematics. Rooted in the nature of thinking, fuzziness is one of the most prominent characteristics of human thinking and judgment of things. The fuzzy set theory is an effective tool to deal with fuzzy phenomenon. By a mathematic method, the theory produces clear results in a systematic manner. It is capable of solving problems that are fuzzy in nature and difficult to quantify and applicable to various uncertain issues.

In 1970s, AHP is proposed by Saaty, an American expert on operations research. It uses a certain scale to objectively quantify the subjective judgments by human beings, and tries to minimize the drawbacks of subjective assumptions. The multi-criteria evaluation method combines quantification and qualification. It is systematic, hierarchical, simple and practical. Thanks to its practicality and effectiveness in handling complex decision-making problems, the method quickly attracted academic interest across the world.

The fuzzy comprehensive evaluation refers to the process of setting up a hierarchal model, determining the weight of indices with AHP, evaluating index membership, and coming to an integrated and comprehensive evaluation through matrix calculation. The steps are as follows.

\subsection{Establishing a set of evaluation factors}

Establish a set of evaluation factors, i.e. the system of evaluation indices. Suppose the evaluation system is $U$, $U=\left\{u_{1}, u_{2}, \ldots, u_{n}\right\}$ will be the set of factors, where $u_{i}$ stands for the $i^{\text {th }}$ object that has an impact on the system.

\subsection{Determining the set of weights}

According to the factors of a complex system and the relationship between the factors, AHP constructs a hierarchal model, making the system much more organized as it divides the factors into hierarchies, and compares the factors on each hierarchy in pairs. Then, it adopts the scale for relative importance of a certain scale theory, sets up a judgment matrix, and calculates the maximum eigenvalue and eigenvector of the judgment matrix. On this basis, AHP obtains the order of relative importance of each factor on a certain hierarchy to another factor on the next hierarchy, thereby establishing the weight vector.

\subsection{Constructing the judgment matrix}

After the construction of the evaluation index system, the affiliation between indices on the upper and lower hierarchies is determined. Compare the importance of the factors on each hierarchy in pairs to form a judgment matrix made up of the coefficients of pair-wise comparisons. Suppose $n$ secondary indices, e.g. $S_{1}, S_{2}, \ldots$, $S_{n}$, all fall into the judgment matrix $\boldsymbol{R}$ which is set up according to the first index $X$ :

$$
\boldsymbol{R}=\left(S_{i j}\right)\left(S_{i j}\right)_{n \times n}=\left[\begin{array}{cccc}
S_{11} & S_{12} & \cdots & S_{1 n} \\
S_{21} & \ddots & \vdots & \vdots \\
\vdots & \cdots & \ddots & \vdots \\
S_{n 1} & S_{n 2} & \cdots & S_{n n}
\end{array}\right]
$$

where, $S_{i j}$ refers to the importance of the index $S_{i}$ in relation to the index $S_{i}$. During the pair-wise comparison, it is represented by figures 1 to 9 . See Tab. 2 for the meaning represented by the figures.

Table 2 Saaty's scale for AHP pairwise comparisons [29, 30]

\begin{tabular}{|c|l|}
\hline Weight & \multicolumn{1}{c|}{ Description } \\
\hline 1 & Equal importance \\
\hline 3 & Moderately more important \\
\hline 5 & Strongly more important \\
\hline 7 & Very strongly more important \\
\hline 9 & Dominant importance \\
\hline $2,4,6,8$ & Reciprocals \\
\hline
\end{tabular}

\subsection{Establishing evaluation set}

Select a number of evaluation sets to form an evaluation set $V=\left\{v_{1}, v_{2}, \ldots, V_{m}\right\}$, and divide the evaluation criteria into $m$ grades.

Based on this first index's judgment matrix, the weights of every first index can be calculated by the geometric calculation method of mean.

$\bar{\omega}_{i}=\sqrt[n]{\prod_{j=1}^{n} \mathrm{~S}_{i j}} \quad(i=1,2, \ldots, n)$

Then making the normalized processing, using the following formula:

$\omega_{i}=\frac{\bar{\omega}_{i}}{\sum_{i=1}^{n} \bar{\omega}_{i}} \quad(i=1,2, \ldots, n)$

The weight vector of first index is obtained: $\omega=\left(\omega_{1}, \omega_{2}, \ldots, \omega_{n}\right)^{\mathrm{T}}$.

The largest characteristic roots $\lambda_{\max }$ can be calculated by the following formula:

$\lambda_{\max }=\frac{1}{n} \sum_{i=1}^{n} \frac{(A W)_{i}}{W_{i}} \quad(i=1,2, \ldots, n)$

However, due to the extreme complexity of objective things, the influencing factors of subjective understanding occasionally cannot entirely meet the requirement of consistency. Thus, checking the matrix for consistency is necessary, and the process is as follows. 
The consistency ratio requirements: $C . R=\frac{C . I}{R . I}<0.1$. $C . I=\frac{\lambda_{\max }-n}{n-1}$. The mean random consistency index R.I is showed in Tab. 3 .

\subsection{Comprehensive evaluation}

Determine the set of memberships $R$ based on the opinions and scores of experts, obtain the comprehensive evaluation value of each hierarchy in accordance with Eq. (5), and acquire the final evaluation of the project with the maximum membership method or the weighted average method.

$F=\omega R=\left(\omega_{1}, \omega_{2}, \ldots, \omega_{n}\right)\left[\begin{array}{cccc}S_{11} & S_{12} & \ldots & S_{1 n} \\ S_{21} & \ddots & \vdots & \vdots \\ \vdots & \ldots & \ddots & \vdots \\ S_{n 1} & S_{n 2} & \cdots & S_{n n}\end{array}\right]$.

\subsection{Programmatic implementation of FAHP}

The FAHP can be implemented by the simulation program Matlab, short for "Matrix Laboratory". It is widely used in areas like numerical calculation, numerical analysis, signal processing, system control, and so on. Thanks to two powerful toolboxes, the program not only supports numerical calculation, but also symbolic computing, graphics modelling and simulation, word processing, etc. More importantly, it is a strong professional program applicable to a wide range of scientific fields. That is why it is so popular among researchers. The Matlab simulation program of FAHP is given in the appendix.

Table 3 The mean random consistency index

\begin{tabular}{|c|c|c|c|c|c|c|c|c|c|c|c|c|c|}
\hline Order & 2 & 3 & 4 & 5 & 6 & 7 & 8 & 9 & 10 & 11 & 12 & 13 & 14 \\
\hline$R . I$ & 0 & 0.52 & 0.86 & 1.10 & 1.26 & 1.34 & 1.40 & 1.43 & 1.49 & 1.51 & 1.54 & 1.56 & 1.58 \\
\hline
\end{tabular}

Table 4 The weights of hierarchy

\begin{tabular}{|c|c|c|c|}
\hline Total index & First index & Secondary index & Third index \\
\hline \multirow{32}{*}{$X$} & \multirow{10}{*}{$\begin{array}{c}F_{1} \\
(0.3)\end{array}$} & \multirow{3}{*}{$\begin{array}{c}S_{1} \\
(0.341)\end{array}$} & $T_{1}(0.305)$ \\
\hline & & & $T_{2}(0.37)$ \\
\hline & & & $T_{3}(0.325)$ \\
\hline & & \multirow{5}{*}{$\begin{array}{c}S_{2} \\
(0.361)\end{array}$} & $T_{4}(0.087)$ \\
\hline & & & $T_{5}(0.285)$ \\
\hline & & & $T_{6}(0.306)$ \\
\hline & & & $T_{7}(0.225)$ \\
\hline & & & $T_{8}(0.097)$ \\
\hline & & \multirow{2}{*}{$\begin{array}{c}S_{3} \\
(0.298)\end{array}$} & $T_{9}(0.6)$ \\
\hline & & & $T_{10}(0.4)$ \\
\hline & \multirow{6}{*}{$\begin{array}{c}F_{2} \\
(0.339)\end{array}$} & \multirow{2}{*}{$\begin{array}{c}S_{4} \\
(0.25) \\
\end{array}$} & $T_{11}(0.5)$ \\
\hline & & & $T_{12}(0.5)$ \\
\hline & & \multirow{4}{*}{$\begin{array}{c}S_{5} \\
(0.75)\end{array}$} & $T_{13}(0.532)$ \\
\hline & & & $T_{14}(0.127)$ \\
\hline & & & $T_{15}(0.172)$ \\
\hline & & & $T_{16}(0.169)$ \\
\hline & \multirow{10}{*}{$\begin{array}{c}F_{3} \\
(0.251)\end{array}$} & \multirow{8}{*}{$\begin{array}{c}S_{6} \\
(0.75)\end{array}$} & $T_{17}(0.08)$ \\
\hline & & & $T_{18}(0.095)$ \\
\hline & & & $T_{19}(0.091)$ \\
\hline & & & $T_{20}(0.139)$ \\
\hline & & & $T_{21}(0.157)$ \\
\hline & & & $T_{22}(0.125)$ \\
\hline & & & $T_{23}(0.215)$ \\
\hline & & & $T_{24}(0.098)$ \\
\hline & & \multirow{2}{*}{$\begin{array}{c}S_{7} \\
(0.25)\end{array}$} & $T_{25}(0.75)$ \\
\hline & & & $T_{26}(0.25)$ \\
\hline & \multirow{6}{*}{$\begin{array}{c}F_{4} \\
(0.11)\end{array}$} & \multirow{3}{*}{$\begin{array}{c}S_{8} \\
(0.5)\end{array}$} & $T_{27}(0.199)$ \\
\hline & & & $T_{28}(0.386)$ \\
\hline & & & $T_{29}(0.415)$ \\
\hline & & \multirow{3}{*}{$\begin{array}{c}S_{9} \\
(0.5)\end{array}$} & $T_{30}(0.182)$ \\
\hline & & & $T_{31}(0.428)$ \\
\hline & & & $\left.T_{32} 0.39\right)$ \\
\hline
\end{tabular}

\section{Case study}

\subsection{Overview of Harbin-Dalian high-speed railway}

Being a key project in China's $11^{\text {th }}$ Five Year Plan, the Harbin-Dalian Passenger Dedicated Line is a part of
Beijing-Harbin Passenger Dedicated Line, a trunk line among the "four vertical and four horizontal" passenger line network of the "Medium and Long-term Railway Network Planning" approved by the State Council. Located in the extremely cold northernmost region in 
China, the line is constructed with the strictest construction standards. It is also the world's first highspeed railway in severe cold region. The line links Harbin, capital of China's northernmost province of Heilongjiang, and the port city of Dalian in Liaoning province, passing through 4 sub-provincial cities (Dalina, Shengyang, Changchun, and Harbin), and 6 prefecturelevel cities (Yingkou, An'shan, Liaoyang, Tieling, Siping and Songyuan). The total length stands at $921 \mathrm{~km}$, including $81 \mathrm{~km}$ in Heilongjiang Province, $270 \mathrm{~km}$ in Jilin Province, and $553 \mathrm{~km}$ in Liaoning Province. There are 23 stations along the route. According to the statistics of 2015 , the 10 cities accounts for $59.87 \%$ of the total GDP, $46.53 \%$ of population, and $40.90 \%$ of tourism resources in Northeast China [31]. The opening of the railway would certainly provide a new boost to the tourism in these cities and across Northeast China.

Harbin-Dalian High-Speed Railway overcomes "forest heaving", a Gordian knot in roadbed control. The designers mastered a complete set of technologies for high-speed railway in severe cold region. For instance, the trains are specially designed to run in the bitter cold environment, and equipment like traction power supply and communication signal system also adapt to low temperature. $847 \mathrm{~km}$ of double ballastless tracks are laid along the route, using China Railway Track System (CRTS) I slab (post-tensioned, two-way pre-stressed, concrete) ballastless tracks anywhere except for sidings, where sleeper-embedded ballastless tracks are used. The slabs of CRTS I ballastless track are designed as: A number of bridges were built for the railway. For example, Mazongtun Extra-Large Bridge is as long as $8.019 \mathrm{~km}$. The 23 arches over the Hunhe River in Shengyang are supported by a 950 ton post-tensioned prestressed concrete box girder. Each arch is $34.4 \mathrm{~m}$ long, $13.4 \mathrm{~m}$ wide. The girder technology is different from anywhere else on the railway. Wenguantun Extra-Large Bridge is known for its $60 \mathrm{~m}+100 \mathrm{~m}+60 \mathrm{~m}$ continuous girder, the longest of its kind on the railway. The girder crosses the busy Beijing-Harbin Railway in close range at an angle of $18^{\circ}$. In areas along the route, the extreme minimum temperature in winter is as low as $-40{ }^{\circ} \mathrm{C}$, the maximum snow thickness is $30 \mathrm{~cm}$, and the maximum depth of frozen soil is $205 \mathrm{~cm}$. To ensure operating safety, all the 27 stations (yards, offices) are provided with snowmelting devices.

Table 5 Classification standard

\begin{tabular}{|c|c|c|c|c|c|}
\hline Level & Very poor $\left(\mathrm{V}_{5}\right)$ & Poor $\left(\mathrm{V}_{4}\right)$ & Qualified $\left(\mathrm{V}_{3}\right)$ & Good $\left(\mathrm{V}_{2}\right)$ & Excellent $\left(\mathrm{V}_{1}\right)$ \\
\hline Score & $\leq 59$ & $60 \sim 69$ & $70 \sim 79$ & $80 \sim 89$ & $\geq 90$ \\
\hline
\end{tabular}

Table 6 Expert evaluation results

\begin{tabular}{|c|c|c|c|c|c|}
\hline Third index & Very poor & Poor & Qualified & Good & Excellent \\
\hline$T_{1}$ & 0 & 0 & 1 & 5 & 2 \\
\hline$T_{2}$ & 0 & 0 & 1 & 5 & 2 \\
\hline$T_{3}$ & 0 & 0 & 0 & 4 & 4 \\
\hline$T_{4}$ & 0 & 0 & 0 & 4 & 4 \\
\hline$T_{5}$ & 0 & 0 & 1 & 4 & 3 \\
\hline$T_{6}$ & 0 & 0 & 0 & 6 & 2 \\
\hline$T_{7}$ & 0 & 1 & 2 & 4 & 1 \\
\hline$T_{8}$ & 0 & 0 & 0 & 5 & 3 \\
\hline$T_{9}$ & 0 & 0 & 1 & 4 & 3 \\
\hline$T_{10}$ & 0 & 0 & 0 & 6 & 2 \\
\hline$T_{11}$ & 0 & 0 & 1 & 4 & 3 \\
\hline$T_{12}$ & 0 & 1 & 1 & 4 & 2 \\
\hline$T_{13}$ & 0 & 0 & 0 & 5 & 3 \\
\hline$T_{14}$ & 0 & 0 & 4 & 4 & 0 \\
\hline$T_{15}$ & 0 & 0 & 1 & 6 & 1 \\
\hline$T_{16}$ & 0 & 0 & 1 & 6 & 1 \\
\hline$T_{17}$ & 0 & 0 & 0 & 5 & 3 \\
\hline$T_{18}$ & 0 & 0 & 0 & 7 & 1 \\
\hline$T_{19}$ & 0 & 0 & 1 & 5 & 2 \\
\hline$T_{20}$ & 0 & 0 & 1 & 5 & 2 \\
\hline$T_{21}$ & 0 & 0 & 0 & 5 & 3 \\
\hline$T_{22}$ & 0 & 0 & 0 & 4 & 4 \\
\hline$T_{23}$ & 0 & 1 & 1 & 5 & 1 \\
\hline$T_{24}$ & 0 & 0 & 0 & 6 & 2 \\
\hline$T_{25}$ & 0 & 0 & 0 & 4 & 4 \\
\hline$T_{26}$ & 0 & 1 & 1 & 4 & 2 \\
\hline$T_{27}$ & 0 & 0 & 0 & 6 & 2 \\
\hline$T_{28}$ & 0 & 0 & 0 & 5 & 3 \\
\hline$T_{29}$ & 0 & 0 & 0 & 6 & 2 \\
\hline$T_{30}$ & 0 & 0 & 0 & 6 & 2 \\
\hline$T_{31}$ & 0 & 0 & 0 & 5 & 3 \\
\hline$T_{32}$ & 0 & 0 & 1 & 5 & 2 \\
\hline
\end{tabular}

4.2 Fuzzy comprehensive evaluation of Harbin-Dalian highspeed railway construction project
The evaluation index system has three hierarchies. The index set on the first hierarchy is: $X=\left\{F_{1}, F_{2}, F_{3}, F_{4}\right\}$. On the second hierarchy, there are 4 index sets, namely 
$F_{1}=\left\{S_{1}, S_{2}, S_{3}\right\}, F_{2}=\left\{S_{4}, S_{5}\right\}, F_{3}=\left\{S_{6}, S_{7}\right\}, F_{4}=\left\{S_{8}, S_{9}\right\}$. The index set on the third hierarchy has 9 indices, including the secondary index $S_{i}$ and all the third indices corresponding to $S_{i}$ (Tab. 1).

After the construction of the index system, use AHP to determine the weights. Ask experts to assign values to the relative importance of indices, seek the weights of indices after the assignment by each expert, and take the arithmetic mean of the weights as the final results (Tab. 4).

Classify the index set $V=\left\{v_{1}, v_{2}, \ldots, v_{m}\right\}$ into five grades: very poor, poor, qualified, good and excellent, as shown in Tab. 5.

Invite 8 experts to score the 32 indices based on the above classification. The results are displayed in Tab. 6 . The figures in that table represent the number of experts who put a certain index under a certain grade. The membership of an index is obtained by dividing the total number of experts with the number of experts who put the index under a certain grade.

\subsection{Matlab simulation calculation}

According to the weights and the expert evaluation results, the evaluation indices are processed in Matlab7.0 on Win32. See Fig. 2 for the results.

In accordance with Fig. 2(a), the maximum membership of the process evaluation is good, indicating that the project performs well in the decision-making process, construction process and operation process. The performance is mainly demonstrated by the following factors. First, the decision-making is very scientific. The route links up 4 sub-provincial cities and 6 prefecture-level cities. Second, the technical indices of the project are in full compliance with design requirements, solving the technical problem of road bed frost heaving in severe cold region and the problem of snow accumulation along the route. Third, the ridership, operating cost, equipment utilization, and other indices have all reached the desired level after the railway was put into service. However, the project lags behind in investment control, mainly because of the construction difficulty and technical complexity in severe cold region. Similar projects in future should attach great importance to the issue.

In accordance with Fig. 2(b), the result of the economic benefit evaluation of the railway is good, indicating that the project has good financial benefit and economic benefit. Harbin-Dalian High-Speed Railway has greatly contributed to GDP, significantly promoted the regional economy in Northeast China, optimized resource allocation and improved resource utilization, accelerated the industrial restructuring process, and tremendously motivated the development of the tertiary industry in the 3 provinces, especially tourism. However, due to high investment and huge loans, the early phase of operation is overshadowed by huge pressure of repayment, resulting in poor financial performance.

In accordance with Fig. 2(c), the result of impact evaluation of the railway is good, indicating good social impact and environmental impact. The successful construction of the project has improved the international prestige of China, solved the tension of transportation capacity in Northeast China, optimized regional transportation structure, promoted the development of the transportation industry, reduced the residents' travel time, and increased the income of residents living along the route. However, in terms of environmental impact, the pollution control of the project has yet to be improved, and the noise and electromagnetic radiation generated during the operation of the railway has an effect on the daily life of the residents.

In accordance with Fig. 2(d), the result of sustainability evaluation of the project is good, indicating good overall sustainability. The sustainability is showcased by its advanced technology, high popularity, high ridership and sound mechanism. Besides, a virtuous circle is formed as the railway promotes the regional economy in Northeast China, which, in return, increases the demand for the railway.

In accordance with Fig. 2(e), the maximum membership of the overall evaluation of the railway is good, indicating that the world's first high speed project in severe cold region is very successful. The project has achieved good results and promoted economic cooperation in Northeast China as it strengthens the link between central and southern Liaoning with the hinterland of Northeast China. The operation of Harbin-Dalian HighSpeed Railway has an important role in promoting for future transport capacity development in Northeast China, Harbin-Dalian High-Speed Railway creates a new economic circle, the speed of convection is accelerating between the major economic circles, it promotes the rapid flow, logistics, information flow in Northeast China, reduces the time from the northeast to vast areas, plays an important role in the revitalization of northeast old industrial base. Harbin-Dalian High-Speed Railway will also change the northeast traffic and economic and social development pattern. Harbin, Shenyang, Changchun will each other into $1.5 \mathrm{~h}$ economic circle, traffic tracks between cities will dock quickly, along the high-speed railway each city's education, medical, leisure, entertainment and other resources are shared on a larger platform, boosting infrastructure sharing among cities, equalization of public services, and accelerating regional economic integration, its "city effect" is obvious. Harbin Dalian high-speed railway is a main artery to strengthen ties in the three provinces, it has built up most of the high quality resources in the three provinces along the line, and its opening will greatly promote the development of local tourism. Northeast tourism has entered the "high-speed tourism era". The opening and operators of Harbin-Dalian High-Speed Railway releases transportation capacity, shortens the time for passenger and freight transport, intercity driving exchanges, stimulating tourism consumption, promotes the economic development of the northeast old industrial base, and it will make an invaluable contribution. A variety of financing methods should be adopted in the investment and financing of highspeed railway, and risk control measures of investment and financing should be strengthened, promoted.

The analysis shows that this paper establishes the post evaluation system of the high-speed railway construction project and calculation, combines the model of FAHP, carries out simulation calculation with Matlab, then combines with Harbin-Dalian High-Speed Railway to evaluate. The evaluation results are consistent with the 
construction and status of operation of high-speed railway. China railway high-speed has accounted for an absolute share of the global market, its possession and operations mileage have reached the forefront of the world, but still face fierce competition risk. The post evaluation system of high-speed railway construction project is scientific, feasible and universal, it can improve the standard system of China high-speed railway from product design, construction and operation, so as to improve its ability to resist risks.
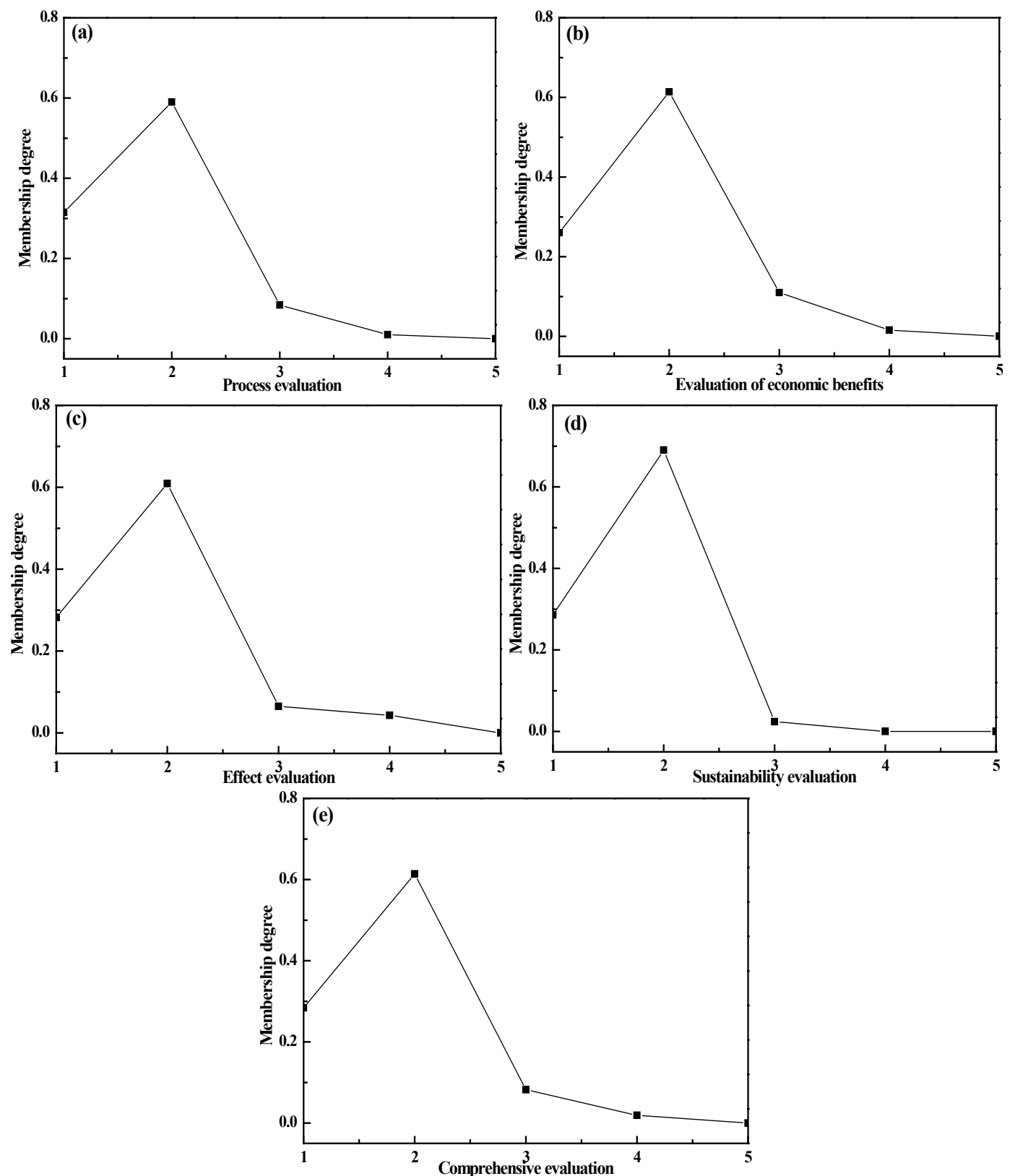

Figure 2 The results of post evaluation on Harbin-Dalin high-speed railway construction project (a)-Process evaluation; (b)- Evaluation of economic benefits; (c)-Effect evaluation; (d)-Sustainability evaluation; (e)-Comprehensive evaluation

\section{Conclusions}

This study comprehensively considers the many factors affecting post evaluation on high- speed construction project. The index system is established from the four aspects of process evaluation, evaluation of economic benefits, effect evaluation and sustainability evaluation. The comprehensive evaluation is carried out using the FAHP model and Matlab simulation calculation. It provides a reliable basis for post evaluation on highspeed railway construction project.

The various evaluation factors do not all carry the same level of importance in the evaluation system of post evaluation on high-speed railway construction project, so it is necessary to determine the weight of each factor. The modified AHP that simultaneously achieves qualitative and quantitative evaluation is used. The weights are assigned in a more scientific and rational manner and satisfy the requirement of consistency, thus fully reflecting the significance level of each evaluation index.

Citing an actual project as an example, this paper proves that a universally applicable way to overcome the complex calculation and heavy computational burden of three-layer models is to conduct simulation with Matlab according to the principle of FAHP. It shows that the combination of Matlab and mathematic models can be effectively applied to post evaluation of high-speed railway construction projects in real life. 
In the post evaluation of Harbin-Dalian High-Speed Railway project, the project receives good results in process evaluation, economic benefit evaluation, impact evaluation and sustainability evaluation. The project selected an appropriate route thanks to proper technical plans for survey and design during preliminary decisionmaking, guaranteed work safety during construction, promoted industrial restructuring, tourism and GDP in Northeast China during project operation. Meanwhile, the residents living along the route saw increase on income and per capita GNP. With increasing ridership and popularity, the project has eased the tension of transportation capacity in the region.

The deviation in investment control during the construction process reflects the importance of cost estimation for similar projects in severe cold regions. Due to high investment, the early phase of operation is overshadowed by huge pressure of repayment, resulting in poor financial performance. However, the financial revenue will increase with the ridership. Because the noise and electromagnetic radiation generated during the operation of high-speed railway has an effect on the daily life of the residents, the author suggests widening the relocation distance for residents living along the route and adding noise and radiation protection facilities.

\section{Acknowledgment}

This research was financed primarily by the National Natural Science Foundation of China (41511130033, 41271556).

\section{Appendix}

The Matlab simulation program of FAHP is as follows:

Clc; clear;

$\mathrm{A}=\operatorname{input}\left({ }^{\mathrm{A}} \mathrm{A}=\mathrm{\prime}\right)$; envalue)

$[\mathrm{x}, \mathrm{y}]=\operatorname{eig}(\mathrm{A}) ;$ eigenvalue $=\operatorname{diag}(\mathrm{y}) ; \operatorname{lamda} 1=\max ($ eig

$\mathrm{x}=$ ones $(\mathrm{n}, 100)$

$\mathrm{y}=$ ones $(\mathrm{n}, 100)$

$\mathrm{m}=$ zeros $(1,100)$;

$\mathrm{m}(1)=\max (\mathrm{x}(:, 1))$;

$\mathrm{y}(:, 1)=\mathrm{x}(:, 1)$;

$\mathrm{x}(:, 2)=\mathrm{A} * \mathrm{y}(:, 1)$;

$\mathrm{m}(2)=\max (\mathrm{x}(:, 2))$

$\mathrm{y}(:, 2)=\mathrm{x}(:, 2) / \mathrm{m}(2)$

$\mathrm{p}=0.0001 ; \mathrm{i}=2 ; \mathrm{k}=\mathrm{abs}(\mathrm{m}(2)-\mathrm{m}(1))$;

while $\mathrm{k}>\mathrm{p} \%$ When $\mathrm{k}>\mathrm{p}$ is Execution cycle

$\mathrm{i}=\mathrm{i}+1 ; \% \mathrm{i}$ Since the 1

$(:, i)=A^{*} y(:, i-1)$;

$\mathrm{m}(\mathrm{i})=\max (\mathrm{x}(:, \mathrm{i}))$

$\mathrm{y}(:, \mathrm{i})=\mathrm{x}(:, \mathrm{i}) / \mathrm{m}(\mathrm{i})$;

$\mathrm{k}=\operatorname{abs}(\mathrm{m}(\mathrm{i})-\mathrm{m}(\mathrm{i}-1))$;

end

$\mathrm{a}=\operatorname{sum}(\mathrm{y}(:, \mathrm{i}))$;

$\mathrm{w}=\mathrm{y}(:, \mathrm{i}) / \mathrm{a}$;

$\mathrm{t}=\mathrm{m}(\mathrm{i})$;

$\operatorname{disp}(\mathrm{w})$;

$\operatorname{disp}(\mathrm{t})$;

$\%$ The following is the consistency test

$\mathrm{CI}=(\mathrm{t}-\mathrm{n}) /(\mathrm{n}-1)$;

$\mathrm{RI}=\left[\begin{array}{llllllllll}0 & 0 & 0.52 & 0.86 & 1.10 & 1.26 & 1.34 & 1.40 & 1.43 & 1.49\end{array}\right.$

$\left.\begin{array}{llll}1.5 & 1.54 & 1.56 & 1.58\end{array}\right]$
$\mathrm{CR}=\mathrm{CI} / \mathrm{RI}(\mathrm{n})$

if $\mathrm{CR}<0.10$

disp('The consistency of this matrix can be accepted!');

$\operatorname{disp}(' \mathrm{CI}=') ; \operatorname{disp}(\mathrm{CI})$;

$\operatorname{disp}(' \mathrm{CR}=$ '); $\operatorname{disp}(\mathrm{CR})$;

else

disp('The consistency of this matrix is not acceptable!');

end

\section{References}

[1] Bell, J. R.; Burton, D.; Thompson, M. C.; Herbst, A. H.; Sheridan, J. Dynamics of trailing vortices in the wake of a generic high-speed train. // Journal of Fluids \& Structures. 65, (2016), pp. 238-256

https://doi.org/10.1016/j.jfluidstructs.2016.06.003

[2] Campos, J.; Ginés, D. R.; Ignacio, B. Some stylized facts about high-speed rail: a review of HSR experiences around the world. // Transport Policy. 16, 1(2009), pp. 19-28. https://doi.org/10.1016/j.tranpol.2009.02.008

[3] He, G. Z.; Mol, A.P. J.; Zhang, L.; Lu, Y. L. Environmental risks of high-speed railway in China: Public participation, perception and trust. // Environmental Development. 14, (2015), pp. 37-52. https://doi.org/10.1016/j.envdev.2015.02.002

[4] Zhang, Q.; Yang, H. J.; Wang, Q. Impact of high-speed rail on China's Big Three airlines. // Transportation Research Part A: Policy and Practice. 98, (2017), pp. 77-85. https://doi.org/10.1016/j.tra.2017.02.005

[5] Nakagawa, D.; Hatoko, M. Reevaluation of Japanese highspeed rail construction: recent situation of the north corridor Shinkansen and its way to completion. // Transport Policy. 14, 2 (2007), pp. 150-164. https://doi.org/10.1016/.t.tranpol.2006.11.004

[6] Wolch, J. R.; Byrne, J.; Newell, J. P. Urban green space, public health, and environmental justice: The challenge of making cities 'just green enough'. // Landscape \& Urban Planning, 125, (2014), pp. 234-244. https://doi.org/10.1016/j.landurbplan.2014.01.017

[7] Chen, Z. H.; Xue, J. B.; Rose, A. Z.; Haynes, K. E. The effect of high-speed rail investment on economic and environmental change in China: A dynamic CGE analysis. // Transportation Research Part A: Policy and Practice. 92, (2016), pp. 232-245. https://doi.org/10.1016/j.tra.2016.08.006

[8] Huang, Y. P. Understanding China's Belt \& Road Initiative: Motivation, framework and assessment. // China Economic Review. 40, (2016), pp. 314-321. https://doi.org/10.1016/j.chieco.2016.07.007

[9] National Development and Reform Commission. Administrative Measures for Post Evaluation of Central Government-funded Projects (for trial implementation) (NDRC/Investment [2008] No. 2959). China Planning Press, Beijing, 2008.

[10] Levinson, D.; Mathieu, J. M.; Gillen, D.; Kanafani, A. The full cost of high-speed rail: an engineering approach. // The Annals of Regional Science. 31, 2(1997), pp. 189-215. https://doi.org/10.1007/s001680050045

[11] Qu, Y.; Bektaş, T.; Bennell, J. Sustainability SI: Multimode multicommodity network design model for intermodal freight transportation with transfer and emission costs. // Networks and Spatial Economics. 16, 1(2016), pp. 303-329. https://doi.org/10.1007/s11067-014-9227-9

[12] Albalate, D.; Bel, G. High-speed rail: lessons for policy makers from experiences abroad. // Public Administration Review. 27, 3(2012), pp. 336-349. https://doi.org/10.1111/j.1540-6210.2011.02492.x 
[13] Redding, S.; Sturm, D.M. The costs of remoteness: evidence from German division and reunification. // American Economic Review. 98, 5(2008), pp. 1766-1797. https://doi.org/10.1257/aer.98.5.1766

[14] Laird, J. J.; Venables, A. J. Transport investment and economic performance: A framework for project appraisal. // Transport Policy. 56, (2017), pp. 1-11. https://doi.org/10.1016/j.tranpol.2017.02.006

[15] Ortega, E; López, E. Territorial cohesion effects of highspeed rail at different planning levels. // Journal of Transport Geography. 24, 9(2012), pp. 130-141. https://doi.org/10.1016/j.jtrangeo.2011.10.008

[16] Guirao, B.; Lara-Galera, A.; Campa, J. L. High Speed Rail commuting impacts on labour migration: The case of the concentration of metropolis in the Madrid functional area. // Land Use Policy. 66, (2017), pp. 131-140. https://doi.org/10.1016/j.landusepol.2017.04.035

[17] Bazin-Benoit, S.; Beckerich, C.; Delaplace, M. High-speed rail, corporate real estate and firm location: the results from two surveys $(2008,2014)$ in Reims. // The Open Transportation Journal. 11, Suppl. 1(2016), pp. 112-131. https://doi.org/10.1177/0042098014560500

[18] Xiao, Y.; Webster,C., Orford, S. Identifying house price effects of changes in urban street configuration: An empirical study in Nanjing, China. // SAGE Journals. 53, 1(2016), pp. 997-1015. https://doi.org/10.1177/0042098014560500

[19] Zhang, F. L. Research on the post evaluation theory and method of the railway construction project. Central South University, Changsha, China, 2004.

[20] Zhang, L.; Li, Q.; Wang, G. F. Analysis and assessment of Chinese railway performance based on DEA technique. // Journal of Systems \& Management. 15, 3(2006), pp. 220224.

[21] Wang, Y. M.; Elhag, T. M. S. Fuzzy TOPSIS method based on alpha level sets with an application to bridge risk assessment. // Expert Systems with Applications. 31, 2(2006), pp. 309-319. https://doi.org/10.1016/j.eswa.2005.09.040

[22] Cucala, A. P.; Fernández, A.; Sicre, C.; Domínguez, M. Fuzzy optimal schedule of high-speed train operation to minimize energy consumption with uncertain delays and driver's behavioral response. // Engineering Applications of Artificial Intelligence. 25, 8(2012), pp. 1548-1557. https://doi.org/10.1016/j.engappai.2012.02.006

[23] Chen, J. H.; Yang, L. R.; Su, M. C.; Lin, J. Z. A rule extraction based approach in predicting derivative use for financial risk hedging by construction companies. // Expert Systems with Applications. 37, 9(2010), pp. 6510-6514. https://doi.org/10.1016/j.eswa.2010.02.135

[24] Chen, X. Y.; Chang, Y. L. The Study of evacuation passenger service level of Shanghai-Nanjing high-speed railway stations. // Procedia - Social and Behavioral Sciences. 96, 6(2013), pp. 265-269. https://doi.org/10.1016/j.sbspro.2013.08.033

[25] Liu, P.; Yang, L. X.; Gao, Z. Y.; Li, S. K.; Gao, Y. Fault tree analysis combined with quantitative analysis for highspeed railway accidents. // Safety Science. 79, (2015), pp. 344-357. https://doi.org/10.1016/j.ssci.2015.06.017

[26] Chen, S. K.; Leng, Y.; Mao, B. H.; Liu, S. Integrated weight-based multi-criteria evaluation on transfer in large transport terminals: A case study of the Beijing South Railway Station. // Transportation Research Part A: Policy and Practice. 66, (2014), pp. 13-26. https://doi.org/10.1016/.tra.2014.04.015

[27] Luca, D. M.; Acqua, G. D.; Lamberti, R. High-speed rail track design using GIS and multi-criteria analysis. // Procedia - Social and Behavioral Sciences. 54, 4(2012), pp. 608-617. https://doi.org/10.1016/j.sbspro.2012.09.778
[28] Zaden, L. A. Fuzzy sets. // Information and Control. 8, 3(1965), pp. 338-353. https://doi.org/10.1016/S0019-9958(65)90241-X

[29] Wang, J. J.; Jing, Y. Y.; Zhang, C. F.; Zhao, J. H. Review on multi-criteria decision analysis aid in sustainable energy decision-making. // Renewable and Sustainable Energy Reviews. 13, 9(2009), pp. 2263-2278. https://doi.org/10.1016/j.rser.2009.06.021

[30] Chang, Y. Z.; Dong, S. C. Evaluation of sustainable development of resources-based cities in Shanxi Province based on unascertained measure. // Sustainability. 8, 6(2016), pp. 585-602. https://doi.org/10.3390/su8060585

[31] National Bureau of Statistics. International city statistical yearbook 2016. China Statistics Press, Beijing, 2016.

\section{Authors' addresses}

\section{Yongzhi Chang, PhD}

Institute of Geographic Sciences and Natural Resources Research the Chinese Academy of Sciences

Jia 11\#, Datun Road, Chaoyang District, Beijing 100101, China E-mail: changyz@igsnrr.ac.cn

\section{Suocheng Dong, Professor PhD}

(Corresponding author)

Institute of Geographic Sciences and Natural Resources Research the Chinese Academy of Sciences

Jia 11\#, Datun Road, Chaoyang District, Beijing 100101, China

E-mail: dongsc@igsnrr.ac.cn 